\title{
The Practicality of Student Activity Sheet Integrated Scientific Approach to Stimulate Skills of Elementary School Students in Solving Problems Surrounding Natural Environment
}

\author{
Gio Mohamad Johan; Lili Kasmini ${ }^{1}$; Pupun Nuryani ${ }^{2}$ \\ ${ }^{1}$ STKIP Bina Bangsa Getsempena, Indonesia \\ ${ }^{2}$ Universitas Pendidikan Indonesia
}

http://dx.doi.org/10.18415/ijmmu.v6i2.765

\begin{abstract}
This study aims to determine the value of the practicality of product development activities sheet students integrated scientific approach. The student activity sheet integrated scientific approach is an activity sheet that presents material, instructions and various kinds of tasks for students by combining scientific approach activities in the form of (1) observing, (2) asking questions, (3) gathering information, (4) processing information, and (5) communicate. This type of research uses research or R \& D (Research and Development). In this research process, the final result is that the development of student activity sheets integrated scientific approach has a high practicality value based on (1) observations of student and teacher activities when using student activity sheets integrated scientific approach to the learning process gets high scores; (2) the results of the readability questionnaire on the student activity sheet integrated scientific approach obtained the average percentage response value of $93.91 \%$ with very high criteria; (3) the results of student questionnaire responses to the use of student activity sheets integrated scientific approach obtain an average percentage response value of $94.35 \%$ with very high criteria.
\end{abstract}

Keywords: Practicality; Students Activity Sheet; Scientific Approach

\section{Introduction}

Some variations and learning innovations conducted by the teacher including the development of teaching materials should be adapted to the applicable curriculum, the level of students' abilities, and the conditions in which students learn so that the learning objectives and achievement of competencies for students are maximally achieved. However, in reality it is still far from that idealism. To achieve the target according to the indicators of success, the teaching materials used by the teacher should be accompanied by student activity sheets (Prastowo, 2014). Student Activity Sheet is the activity of students in learning to apply or practice the knowledge that has been obtained. The student activity sheet is very important to know the success of students in absorbing and mastering the knowledge that has been given. In this study, teaching material products will be developed in the form of student activity sheets integrated scientific approach. In the student activity sheet integrated the scientific approach contains the 
subject matter, questions, activities, information and learning stages students follow a scientific approach which consists of observing, asking, reasoning, gathering information, processing information, and communicating.

The student activity sheet integrated scientific approach serves as a teaching material that can help students conclude a problem. With the activity sheet students integrated this scientific approach, the teacher only needs to act as a facilitator, no longer as the main source of learning. This is also supported by advances in digital technology that have changed the way we interact with people around us, including interactions between students, students with the material, and students with teachers. Teachers in the 21st -century learning no longer transmit knowledge to students, but teachers only need to facilitate the acquisition of students' values, knowledge, and competencies by using inquiry strategies for their learning practices in the classroom (Dembo, 2001).

Shortly before the activity concludes with students, students will choose the right problemsolving step. Students identify the most appropriate steps in solving the problems they face, both, using simple and complex methods. The most important part of the student activity sheet integrated scientific approach has a function to encourage students to do actively, create, work, evaluate or apply science directly in the community (Gürses, Çetinkaya, Doğar, \& Şahin, 2015). Often the use of classical learning models or methods does not encourage students to be directly involved in the learning process. This causes the results achieved to be less than optimal, and the activeness of students and abilities possessed by students is less visible. One factor that directly intersects student learning activities in the classroom and influences students' skills is the existence of learning resources and teaching materials (Podolak \& Podolak, 2013).

One teaching material that can be used is the student activity sheet. The sheet contains a summary of the material and tasks that must be done by students. The student activity sheet is one of the tools to help and facilitate teaching and learning activities. With the existence of the sheet, it will form effective interactions between students and teachers, so that it can improve learning activities and student learning achievements (Arafah, S., Ridlo, \& Priyono, 2012). The student activity sheet prepared can be designed and developed by the conditions and situations of the learning activities that will be faced. Student activity sheets are also learning media because they can be used together with learning resources or other learning media (Widjajanti, 2008).

The function of the student activity sheet is used as a reference to guide the implementation of learning activities and also as a tool for assessing processes in learning. Process assessment can be interpreted as an assessment of the ongoing learning process, which emphasizes the activities and creativity of students in gaining knowledge, skills, values, and attitudes to achieve a goal (Sudaryono, 2012). Using the student activity sheet as a process assessment instrument can help teachers assess the work process and student work outcomes, such as the results of group discussions, experimental activities, evaluation, and independent training. From the results of the assessment, this process can prove that students are able to understand concepts and construct their knowledge more deeply.

The student activity sheet used must be adapted to the science learning approach. The recommended learning approach is a scientifically integrated learning approach (Astuti \& Setiawan, 2013; Atiyah, Wahidin, \& Roviati, 2016; Khairiah, 2013). In understanding the material related to solving environmental problems, it is necessary to understand the concepts of the previous material that is related, so that the students' initial knowledge can be built. Therefore, we need a teaching material that can support the learning process and can help students find the whole concept of knowledge. The main objective of this study is to describe the practicality of integrated student activity sheets in the scientific approach to improve the settlement skills of the natural environment problems of elementary school students which consist of (1) observations on the implementation of student activities when using student activity sheets integrated scientific approach, (2) observation results of the implementation of teacher activities when using student activity sheets integrated scientific approach, (3) the results of student responses to the readability of student activity sheets integrated scientific approach, and (4) the results of student responses during the learning process using student activity sheets integrated scientific approach. 


\section{Methodology}

This type of research is research and development or R \& D (Research and Development) which produces product activity sheets for students integrated scientific approach. Then R \& D (Research and Development) is a research method used to produce certain products, and test the validity, practicality, and effectiveness of these products (Thagarajaan, S., Semmel, D. S., Semmel, 1974). The development model used in this study is a 4-D model of consisting of 4 main stages, namely (1) Define or the definition phase; (2) Design or design stage; (3) Development or development stage; (4) Disseminate or the stage of dissemination (Sugiyono, 2014).

The sample in this study was fourth-grade students of the elementary school in Aceh Besar District, Aceh Province, Indonesia which was taken using purposive sampling technique. Purposive sampling is a technique of determining samples with certain considerations based on certain characteristics that are considered to have a close relationship with the characteristics of the population that have been known before, in other words, the contacted sample units are adjusted to certain criteria applied based on research objectives (Sugiyono, 2014).

This study uses an instrument consisting of (1) Observation sheet, used to measure the activities of teachers and students during the learning process using student activity sheets integrated scientific approach; (2) Questionnaire sheets, used to measure the readability and level of student responses to the learning process when using student activity sheets integrated scientific approach. While the data analysis technique of the results of the instrument is quantitative descriptive.

\section{Result and Discussion}

The results of the practicality of product development assessment of student activity sheets integrated the scientific approach to the learning process based on the data as follows.

1. Based on the results of direct observation for three meetings, the implementation of student activities when using the student activity sheet integrated scientific approach when the learning process can be carried out very well. The implementation of student activities at the first meeting scored 3.73 which means very good or carried out up to $93.13 \%$; in the second meeting the score was 3.85 which means very good or done up to $96.25 \%$; the third meeting scored 3.93 which means very good or done up to $98.33 \%$. The graphic presentation of the implementation of student activities during the process of teaching and learning activities using the student activity sheet integrated scientific approach for three meetings in the experimental class that has been developed by researchers is as follows.

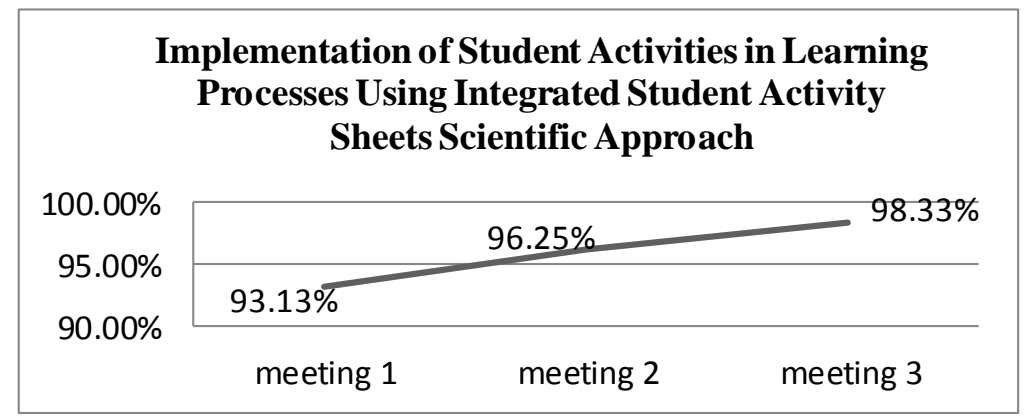

Graph 1. Implementation of Student Activities in Learning Processes Using Student Activity Sheets Integrated the Scientific Approach

2. Based on the results of direct observations during three meetings, the implementation of teacher activities when using the student activity sheet integrated scientific approach can be carried out very well. The application of the use of the student activity sheet integrated scientific approach at the first meeting got a score of 3.48 which means very good or implemented up to $86.97 \%$; in the 
second meeting the score was 3.71 which means very good or implemented up to $92.77 \%$; the third meeting got a rating of 3.94 which means very good or done up to $98.61 \%$. The graphical presentation of the implementation of teacher activities when using student activity sheets integrated scientific approach for three meetings in the experimental class that has been developed by researchers is as follows.

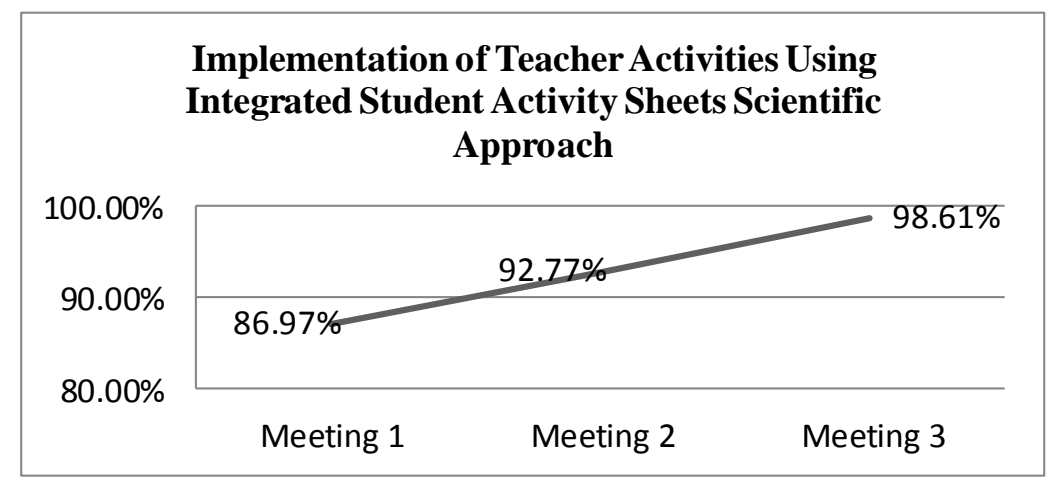

Graph 2. Implementation of Teacher Activities in Learning Processes Using Student Activity Sheets Integrated the Scientific Approach

3. The results of the readability questionnaire of student activity sheets integrated scientific approach with data sources of 23 students in the experimental class are as follows.

Table 1. Results of Questionnaire for Reading Student Activity Sheets Integrated Scientific Approach

\begin{tabular}{llllll} 
& \multicolumn{2}{c}{ Answer } & \multicolumn{2}{c}{ Percentage } & Criteria \\
\cline { 2 - 4 } & Yes & No & Yes & No & \\
\cline { 1 - 4 } $\begin{array}{l}\text { 1. Is the LKS based on the sciei } \\
\text { approach you are reading intere }\end{array}$ & 1 & $96 \%$ & $4 \%$ & very high \\
and & & & &
\end{tabular}

2. Is the appearance and conten $23 \quad 0 \quad 100 \% \quad 0 \% \quad$ very high the LKS based on the scientific approach that you are reading interesting?

\begin{tabular}{|c|c|c|c|c|}
\hline $\begin{array}{l}\text { 3. Are the questions on the LK: } 20 \\
\text { based on the scientific approacl } \\
\text { pleasant to answer? }\end{array}$ & 3 & $87 \%$ & $13 \%$ & very high \\
\hline $\begin{array}{l}\text { 4. Are the images or illustratior } 22 \\
\text { the LKS based on the scientific } \\
\text { approach easy to understand? }\end{array}$ & 1 & $96 \%$ & $4 \%$ & very high \\
\hline $\begin{array}{l}\text { 5. Is the content of the material } 21 \\
\text { contained in the LKS based on } \\
\text { scientific approach easy to } \\
\text { understand? }\end{array}$ & 2 & $91 \%$ & $9 \%$ & very high \\
\hline Total & 7 & $469.57 \%$ & $30.4 \%$ & very high \\
\hline Average & 1.4 & $93.91 \%$ & $6.09 \%$ & \\
\hline
\end{tabular}


Based on table 1, it is known that the response of students in the experimental class to the readability questionnaire sheet of students' integrated scientific approach was $93.91 \%$, giving a positive response with very high criteria.

4. The results of student questionnaire responses to student activity sheets integrated scientific approach with data sources of 23 students in the experimental class are as follows

Table 2. Results of Questionnaire for Student Response to Experimental Classes on Integrated Student Activity Sheets Scientific Approach

\begin{tabular}{|c|c|c|c|c|c|}
\hline \multirow[t]{2}{*}{ Question } & \multicolumn{2}{|c|}{ Answer } & \multicolumn{2}{|c|}{ Percentage } & \multirow[t]{2}{*}{ Criteria } \\
\hline & Yes & No & Yes & No & \\
\hline $\begin{array}{l}\text { 1. Are you easy to understand the material ir } \\
\text { LKS based on the scientific approach? }\end{array}$ & 20 & 3 & $87 \%$ & $13 \%$ & very high \\
\hline $\begin{array}{l}\text { 2. Are you easy to understand images or } \\
\text { illustrations in the LKS based on the scientif } \\
\text { approach? }\end{array}$ & 22 & 1 & $96 \%$ & $4 \%$ & very high \\
\hline $\begin{array}{l}\text { 3. Are you happy in understanding the variol } \\
\text { problems that exist in the surrounding envirc } \\
\text { on the LKS based on the scientific approach }\end{array}$ & 23 & 0 & $100 \%$ & $0 \%$ & very high \\
\hline $\begin{array}{l}\text { 4. Do you easily understand the questions in } \\
\text { LKS based on the scientific approach? }\end{array}$ & 23 & 0 & $100 \%$ & $0 \%$ & very high \\
\hline $\begin{array}{l}\text { 5. Are you easy to understand each sentence } \\
\text { material on the LKS based on the scientific } \\
\text { approach? }\end{array}$ & 21 & 2 & $91 \%$ & $9 \%$ & very high \\
\hline $\begin{array}{l}\text { 6. Is the design of colors and images in the } \mathrm{L} \\
\text { based on a new scientific approach? }\end{array}$ & 22 & 1 & $96 \%$ & $4 \%$ & very high \\
\hline
\end{tabular}

7. Is the LKS cover image based on a scienti $23 \quad 0 \quad 100 \% \quad 0 \% \quad$ very high
approach interesting?

8. Do you like working on the questions in th $20 \quad 3 \quad 87 \% \quad 13 \% \quad$ very high LKS based on the scientific approach?

9. Do you like to develop strategies for solvi $21 \quad 2 \quad 91 \% \quad 9 \% \quad$ very high problems that exist in the LKS based on the scientific approach?

10. Do you like to take part in the lessons the $22 \quad 1 \quad 96 \% \quad 4 \% \quad$ very high teacher has done using the LKS based on the scientific approach?

\begin{tabular}{llllll}
\hline Total & 217 & 13 & $943.48 \%$ & $56.52 \%$ & very high \\
& & & & \\
\cline { 1 - 3 } Average & 21.7 & 1.3 & $94.35 \%$ & $5.65 \%$ &
\end{tabular}


Based on table 2 it is known that the response of students in the experimental class to learning using the student activity sheet integrated scientific approach is equal to $94.35 \%$ giving a positive response with very high criteria.

\section{Conclusion}

Based on the observations of student and teacher activities influenced by several things, namely teacher teaching methods that are clear, firm and pleasant and in learning the teacher involves students to play an active role so that students feel happy to take part in learning. Students are invited by the teacher to make a learning agreement, students are encouraged to discuss the tasks and responsibilities during the learning process. Likewise, students are also invited to determine the consequences that must be accepted if they violate the agreement. Students who have a stake in instructional activities or making school rules have a love for the school and in turn significantly increase their involvement in school activities.

The results of the readability of the student activity sheet integrated scientific approach obtain a very high average value because on the activity sheet the student uses language that is in accordance with the rules of Indonesian language that is good and correct and uses short, solid and clear sentences to be easily understood by students. Also besides, on the activity sheet students integrated the scientific approach equipped with a variety of exciting image illustrations.

The results of student responses to the use of student activity sheets integrated scientific approach also showed a good percentage due to having the appearance of content, language, graphics, and presentation different from the student activity sheet which is usually used by the teacher. Based on this explanation, it can be concluded that the student activity sheet integrated scientific approach has a high practicality value to stimulate students' skills in solving problems of the surrounding natural environment.

\section{References}

Arafah, S., F., Ridlo, S., \& Priyono, B. (2012). Pengembangan Lks Berbasis Berpikir Kritis Pada Materi Animalia. Unnes Journal of Biology Education. https://doi.org/10.1117/12.776759.

Arends, R. (2009). Learning to Teach Ninth Edition. New York: The Mc Graw Hill Company.

Astuti, Y., \& Setiawan, B. (2013). Pengembangan lembar kerja siswa (LKS) berbasis pendeka-tan inkuiri terbimbing dalam pembelajaran kooperatif pada materi kalor. Jurnal Pendidikan IPA Indonesia. https://doi.org/10.15294/jpii.v2i1.2515.

Atiyah, R. I., Wahidin, W., \& Roviati, E. (2016). Penggunaan Lembar Kerja Siswa (LKS) Berbasis Keterampilan Proses Sains (KPS) Untuk Meningkatkan Literasi Sains Siswa Pada Konsep Kingdom Plantae Kelas X Di Sman 3 Kuningan. Scientiae Educatia: Jurnal Sains Dan Pendidikan Sains.

Dembo, M. H. (2001). Learning to teach is not enough - Future teachers also need to learn how to learn. Teacher Education Quarterly.

Gürses, A., Çetinkaya, S., Doğar, Ç., \& Şahin, E. (2015). Determination of Levels of Use of Basic Process Skills of High School Students. Procedia - Social and Behavioral Sciences. https://doi.org/10.1016/j.sbspro.2015.04.243.

Khairiah, N. (2013). Aplikasi Model Pembelajaran dalam Perspektif Pendekatan Saintifik. Medan. 
Podolak, K., \& Podolak, K. (2013). Interactive Modern Physics Worksheets Methodology and Assessment by Students. European Journal of Physics Education. https://doi.org/10.20308/ejpe.03366.

Prastowo, A. (2014). Panduan Kreatif Membuat Bahan Ajar Inovatif. Jogjakarta: Diva Press.

Sudaryono. (2012). Dasar-Dasar Evaluasi Pembelajaran. Yogyakarta: Graha Ilmu.

Sugiyono. (2014). Metode Penelitian Kuantitatif, Kualitatif, dan Kombinasi (Mixed Methods). In Metode Penelitian Kuantitatif, Kualitatif dan R\&D. https://doi.org/10.3354/dao02420.

Thagarajaan, S., Semmel, D. S., Semmel, D. I. (1974). Instructional development for training teacher of exceptional children. Bloomington Indiana: Indiana University.

Widjajanti. (2008). Kualitas Lembar Kerja Siswa. Makalah disampaikan dalam kegiatan pengabdian masyarakat, Yogyakarta, Universitas Negeri Yogyakarta tanggal 28 Agustus 2008 .

\section{Copyrights}

Copyright for this article is retained by the author(s), with first publication rights granted to the journal. This is an open-access article distributed under the terms and conditions of the Creative Commons Attribution license (http://creativecommons.org/licenses/by/4.0/). 